\title{
Purification, characterization and comparison of two non-haem bromoperoxidases from Streptomyces aureofaciens ATCC 10762
}

\author{
Maria Weng, Otto Pfeifer, Susanne Krauss, Franz Lingens and Karl-Heinz van Pée* \\ Institut für Mikrobiologie der Universität Hohenheim, Garbenstr. 30, D-7000 Stuttgart 70, FRG
}

(Received 15 March 1991; revised 8 July 1991; accepted 5 August 1991)

\begin{abstract}
Two non-haem bromoperoxidases (BPO 1 and BPO 2) were purified from the 7-chlorotetracycline-producing strain Streptomyces aureofaciens ATCC 10762. Both enzymes showed azide-insensitive brominating activity, and bromide-dependent peroxidase activity. BPO 1 was a dimer $\left(M_{\mathrm{r}} 65000\right)$ with subunits of identical size $\left(M_{\mathrm{r}} 31000\right)$. The pI was estimated to be 4.5. The enzyme did not cross-react with antibodies raised against the non-haem bromoperoxidase $\left(M_{\mathrm{r}} \mathbf{9 0 0 0 0}\right)$ from $S$. aureofaciens Tü24, a strain that also produces 7-chlorotetracycline. The $M_{\mathrm{r}}$ of BPO 2 was estimated to be 90000 . The enzyme had three identical subunits $\left(M_{\mathrm{r}} 31000\right)$, and its isoelectric point was 3.5, identical with that of the bromoperoxidase from $S$. aureofaciens Tü24. Moreover, BPO 2 was immunologically identical with the bromoperoxidase from $S$. aureofaciens Tü24, although both it and BPO 1 could be distinguished electrophoretically from the latter bromoperoxidase.
\end{abstract}

\section{Introduction}

Halogenated organic products of natural origin are widely distributed. Bacteria produce many chlorinated compounds with antibiotic activity. For example, 7-chlorotetracycline is produced by Streptomyces aureofaciens (Duggar, 1948), chloramphenicol by Streptomyces venezuelae (Ehrlich et al., 1947) and pyrrolnitrin by Pseudomonas pyrrocinia (Arima et al., 1964). Haloperoxidases are believed to catalyse the introduction of halogen into these organic compounds at certain steps during their biosynthesis. These enzymes accept chloride, bromide or iodide ions as substrates in the presence of hydrogen peroxide. Fluoride, however, cannot be oxidized by haloperoxidases (Neidleman \& Geigert, 1986).

Some haloperoxidases of eukaryotes and prokaryotes contain haem as a prosthetic group (Olsen \& Little, 1984; Hewson \& Hager, 1980; van Pée \& Lingens, 1985a). They have peroxidase as well as catalase activity. The reaction mechanism of these enzymes is well known (Neidleman \& Geigert, 1986). Other haloperoxidases possess no haem, and hence are not inhibited by azide (Vilter, 1983; Wiesner et al., 1986); they have no peroxidase activity in the absence of bromide or iodide. However, peroxidase activity is greatly enhanced by the

Abbreviations: BPO 1, BPO 2, bromoperoxidases 1 and 2 from Streptomyces aureofaciens ATCC 10762. presence of bromide or iodide (Vilter; 1984; Krenn et al., 1988). Whereas algal non-haem haloperoxidases need vanadium for halogenating activity (De Boer et al., 1986), bacterial haloperoxidases do not require metal ions or any other cofactor (van Pée et al., 1987; Wiesner et al., 1988). Nothing is known about the reaction mechanism and active site of bacterial non-haem haloperoxidases. Investigation of their properties and comparison of their genes could give some information about the active site. However, bacterial non-haem haloperoxidases are difficult to isolate and are usually available only in very small quantities.

7-Chlorotetracycline is produced by $S$. aureofaciens strains ATCC 10762 and Tü24. From each species, a bromoperoxidase has been isolated but, surprisingly, the properties of the enzyme from ATCC 10762 described by Krenn et al. (1988) were different from those of the enzyme purified from $S$. aureofaciens Tü24 by van Pée $e t$ al. (1987). To check whether differences in the two bromoperoxidases were due to the fact that they were produced by different strains, we purified the ATCC 10762 enzyme and examined its immunological and molecular properties. During the purification a second bromoperoxidase, also mentioned by Krenn et al. (1988), was detected in cell extracts of this strain.

To be able to compare the molecular and catalytic properties, as well as the immunological relationship, of the two bromoperoxidases from $S$. aureofaciens ATCC 10762 , and to obtain information which might help 
towards cloning the corresponding genes, we purified and partially characterized both enzymes.

\section{Methods}

Chemicals. Monochlorodimedone, p-nitrophenyl-agarose, and protein-A-peroxidase were purchased from Sigma. Hydrogen peroxide $(30 \%, v / v)$ and 3,3'-5,5'-tetramethylbenzidine were from Merck, and $o$-dianisidine was purchased from Bayer.

Bacterial strains, culture conditions and plasmids. The 7-chlorotetracycline-producing strain $S$. aureofaciens ATCC 10762, S. aureofaciens Tü24, and $S$. lividans TK64 containing the cloned bromoperoxidase gene from $S$. aureofaciens Tü24 on a plasmid (pHM621) (van Pée, 1988), were used. S. aureofaciens ATCC 10762 was grown in $100 \mathrm{ml}$ flasks containing $25 \mathrm{ml}$ of complex medium (per litre of deionized water: glucose, $4 \mathrm{~g}$; yeast extract, $4 \mathrm{~g}$; malt extract, $10 \mathrm{~g}$; $\mathrm{KCl}, 0.5 \mathrm{~g} ; \mathrm{FeSO}_{4} .7 \mathrm{H}_{2} \mathrm{O}, 20 \mathrm{mg}$ ) for $4 \mathrm{~d}$ at $30^{\circ} \mathrm{C}$ on a rotary shaker. Complex medium ( 1 litre) was inoculated with this culture and incubated for $5 \mathrm{~d}$ at $30^{\circ} \mathrm{C}$. A fermenter containing 20 litres of complex medium was inoculated with this culture. After $96 \mathrm{~h}$ incubation, the contents of the fermenter were transferred to a 200 litre fermenter containing mineral salt medium (per litre of deionized water: glucose, $20 \mathrm{~g}$; DL-isoleucine, $0.4 \mathrm{~g}$; $\mathrm{MgSO}_{4} .7 \mathrm{H}_{2} \mathrm{O}, 0.2 \mathrm{~g} ; \mathrm{KH}_{2} \mathrm{PO}_{4}, 4.5 \mathrm{~g}$; $\mathrm{K}_{2} \mathrm{HPO}_{4}, 10.5 \mathrm{~g} ; \mathrm{NaCl}, 90 \mathrm{mg} ; \mathrm{CaCl}_{2} .2 \mathrm{H}_{2} \mathrm{O}, 90 \mathrm{mg} ; \mathrm{ZnSO}_{4} .7 \mathrm{H}_{2} \mathrm{O}$, $4 \mathrm{mg} ; \mathrm{FeSO}_{4} .7 \mathrm{H}_{2} \mathrm{O}, 9 \mathrm{mg} ; \mathrm{CuSO}_{4} .5 \mathrm{H}_{2} \mathrm{O}, 0.18 \mathrm{mg} ; \mathrm{MgSO}_{4} \cdot \mathrm{H}_{2} \mathrm{O}$, $0.03 \mathrm{mg} ; \mathrm{H}_{3} \mathrm{BO}_{3}, 0.02 \mathrm{mg}$; and $\left(\mathrm{NH}_{4}\right)_{6} \mathrm{Mo}_{7} \mathrm{O}_{24} .4 \mathrm{H}_{2} \mathrm{O}, 0.02 \mathrm{mg}$; Chatterjee et al., 1983) and incubated for $40 \mathrm{~h}$ at $30^{\circ} \mathrm{C}$. S. aureofaciens Tü24 was grown as described for $S$. aureofaciens ATCC 10762 or in medium containing $2 \%(\mathrm{w} / \mathrm{v})$ soybean flour and $2 \%(\mathrm{w} / \mathrm{v})$ mannitol for $5 \mathrm{~d}$. Cultures of $S$. lividans TK64 harbouring recombinant plasmids were grown in soybean flour/mannitol medium containing thiostrepton $\left(5 \mu \mathrm{g} \mathrm{ml}^{-1}\right.$; kindly donated by E. R. Squibb \& Sons Inc., Princeton, NJ, USA).

Enzyme assays. Brominating activity was measured spectrophotometrically (Hewson \& Hager, 1980) with monochlorodimedone (44 mM), $\mathrm{H}_{2} \mathrm{O}_{2}(7.8 \mathrm{mM})$, bromide (100 mM), sodium azide (10 mM) and a suitable amount of enzyme in $1 \mathrm{M}$-sodium acetate buffer (pH 5.5). All assays were started with enzyme, and absorbance changes were measured against appropriate blanks. One unit (U) of bromoperoxidase activity is defined as the amount catalysing the formation of $1 \mu \mathrm{mol}$ monobromomonochlorodimedone $\mathrm{min}^{-1}$. Protein was determined by the Lowry method using bovine serum albumin as a standard.

Electrophoresis. For electrophoresis of native enzymes, $7.5 \%(\mathrm{w} / \mathrm{v})$ polyacrylamide gels (pH 7.5) were used (Maurer, 1964). PAGE in the presence of $0 \cdot 1 \%$ SDS was done according to Schäggar \& von Jagow (1987) using a vertical apparatus with $1 \mathrm{~mm}$ gels (Desaga) or with $0.5 \mathrm{~mm}$ gels (Phase). Proteins from a low molecular mass calibration kit (Pharmacia-LKB) were used as standards.

Analytical isoelectric focusing was done using a horizontal apparatus (Pharmacia-LKB) with a $0.5 \mathrm{~mm}$ polyacrylamide gel $(5 \%, \mathrm{w} / \mathrm{v})$ and carrier ampholytes (Serva) in the $\mathrm{pH}$ range $2-11$. The $\mathrm{pI}$ was determined by comparing the migration rate with standard proteins in the pI range 2.5-6 (Pharmacia-LKB). Gels were stained for protein with Serva Blue $\mathrm{R}$ and for peroxidase activity with $o$-dianisidine in the presence of $0.1 \mathrm{M}$-sodium bromide to form brown bands (Shannon $e t$ al., 1966). Brominating activity was detected by conversion of phenol red to bromophenol blue (Loo et al., 1964). The reagent contained $1 \mathrm{M}$ sodium acetate buffer ( $\mathrm{pH} 5.5$ ), $0.002 \%$ phenol red, $1 \mathrm{M}$-sodium bromide, $10 \mathrm{~mm}$-sodium azide and $15 \cdot 6 \mathrm{mM}-\mathrm{H}_{2} \mathrm{O}_{2}$.

Production of antisera. Purified bromoperoxidase $(1 \mathrm{ml})$ from S. aureofaciens Tü 24 at a concentration of $5 \mathrm{mg} \mathrm{ml}^{-1}$ in PBS was mixed
1:1 with incomplete Freund's adjuvant and injected subcutaneously at seven points into a rabbit. After 4 weeks a booster injection was given with the same solution. After 2 weeks the same amount of bromoperoxidase was injected again twice. The rabbit was bled and the blood was collected in tubes and centrifuged.

Ouchterlony gel diffusion assay. Agarose (5\%,w/v) with 0.05\% (w/v) sodium azide in $0.1 \mathrm{M}$-potassium phosphate buffer $(\mathrm{pH} \mathrm{7.5)}$ was used to fill a plate with agarose bond film (Pharmacia-LKB) to a height of $0.5 \mathrm{~cm}$. The assay was done as described by Ouchterlony (1948).

Electroblotting of proteins, sequencing and amino acid analysis. Proteins separated by native PAGE were transferred to a nitrocellulose filter $(0.2 \mu \mathrm{m}$ pore size; Schleicher and Schuell) with an LKB Multiphor NovaBlot apparatus. Electroblotting was done with the discontinuous buffer system for isoelectric focusing gels as described in the LKB manual. For amino acid sequencing, proteins were transferred to an Immobilon PVDF membrane (Millipore) at a constant current of $0.8 \mathrm{~mA} \mathrm{~cm}^{-2}$ for $2.5 \mathrm{~h}$. Protein bands were stained with $0.2 \%$ Coomassie brilliant blue in $45 \%(\mathrm{v} / \mathrm{v})$ methanol and $10 \%(\mathrm{v} / \mathrm{v})$ acetic acid for $10-15 \mathrm{~min}$, then destained in $40 \%(\mathrm{v} / \mathrm{v})$ methanol and $7 \%(\mathrm{v} / \mathrm{v})$ acetic acid for 10-15 min. The $\mathrm{NH}_{2}$-terminal amino acid sequence of proteins blotted on Immobilon PVDF was determined with a protein sequencer from Applied Biosystems. For amino acid analysis (Biotronic LC 6000 amino acid analyser), samples were hydrolysed in evacuated, sealed tubes in $6 \mathrm{M}-\mathrm{HCl}$ at $110^{\circ} \mathrm{C}$ for $24,48,72$ and $96 \mathrm{~h}$ (Spackman, 1967). Half-cysteine was determined as cysteic acid after performic acid oxidation (Hirs, 1967). Tryptophan was determined after hydrolysis with p-toluenesulphonic acid (Liu, 1972).

Partial purification of bromoperoxidases from $S$. aureofaciens ATCC 10762 and $T \ddot{u} 24$

Crude extracts. One vol. (1700 $\mathrm{g}$ wet $\mathrm{wt})$ of cells was suspended in 2 vols of $0.2 \mathrm{M}$-Tris $/ \mathrm{H}_{2} \mathrm{SO}_{4}$ buffer $(\mathrm{pH} \mathrm{8.3)}$ and disrupted with a Branson sonifier ( $\mathrm{J} 17-\mathrm{A}$; twenty $30 \mathrm{~s}$ periods, $70 \mathrm{~W}, 4^{\circ} \mathrm{C}$ ). Cell debris was removed by centrifugation for $30 \mathrm{~min}$ at $22100 \mathrm{~g}$.

Ammonium sulphate precipitation. Ammonium sulphate was added to $25 \%$ saturation and the mixture was stirred for $30 \mathrm{~min}$ at $0{ }^{\circ} \mathrm{C}$. After centrifugation at $22100 \mathrm{~g}$ for $30 \mathrm{~min}$, the supernatant solution was brought to $80 \%$ ammonium sulphate saturation. The precipitate was collected by centrifugation, redissolved in $0.1 \mathrm{M}$-sodium acetate buffer (pH 5.5) and dialysed against the same buffer for $15 \mathrm{~h}$. After centrifugation the pellet was discarded and the supernatant solution was dialysed against $0.03 \mathrm{M}$-Tris/ $\mathrm{H}_{2} \mathrm{SO}_{4}$ buffer $(\mathrm{pH} \mathrm{8.3)}$ ) for $15 \mathrm{~h}$.

$D E A E$-Sephacel. The dialysed sample was clarified by centrifugation and applied to a DEAE-Sephacel column (Pharmacia-LKB) $(5.6 \times 10 \mathrm{~cm})$ equilibrated with $0.03 \mathrm{M}$-Tris $/ \mathrm{H}_{2} \mathrm{SO}_{4}$ buffer $(\mathrm{pH} \mathrm{8.3)}$. The column was washed with $0.1 \mathrm{M}-\mathrm{NaCl}$ in $0.03 \mathrm{M}-\mathrm{Tris} / \mathrm{H}_{2} \mathrm{SO}_{4}$ buffer and proteins were eluted with a gradient of $0.1-0.7 \mathrm{M}-\mathrm{NaCl}$ in the same buffer $(800 \mathrm{ml})$. Fractions $(4 \mathrm{ml})$ were assayed for protein $\left(A_{280}\right)$ and brominating activity as described above. Fractions containing bromoperoxidase activity were pooled separately as BPO 1 and BPO 2 and concentrated by ultrafiltration with a PM-10 membrane (Amicon).

\section{Further purification of bromoperoxidase I (BPO I)}

Heat treatment. 'Pool 1' from the DEAE-Sephacel column was incubated at $75^{\circ} \mathrm{C}$ for $10 \mathrm{~min}$, and the precipitate obtained by centrifugation was discarded. The supernatant solution was dialysed against $0.1 \mathrm{M}$-sodium acetate buffer $(\mathrm{pH} \mathrm{4.6)}$ for $15 \mathrm{~h}$ and then centrifuged. The solution was immediately dialysed against $0.1 \mathrm{M}$-ammonium acetate buffer $(\mathrm{pH} \mathrm{6.8)}$ for $3 \mathrm{~h}$ and then against $10 \mathrm{~mm}$-ammonium acetate buffer ( $\mathrm{pH} \mathrm{6.8)}$ for $15 \mathrm{~h}$. The dialysed extract was concentrated by ultrafiltration with a PM-10 membrane. 
Sephacryl $S 300 H R$. The concentrated extract was applied to a Sephacryl S 300 HR column $(90 \times 2 \mathrm{~cm})$ equilibrated with $0.1 \mathrm{M}$-ammonium acetate buffer ( $\mathrm{pH} 6.8$ ). After elution with the same buffer, fractions were assayed for brominating activity, pooled and concentrated as described above.

Phenyl-Superose HR 5/5. Ammonium sulphate was added to a concentration of $1 \mathrm{M}$ to the solution obtained after Sephacryl S 300 chromatography. The Phenyl-Superose column was eluted with a descending gradient of $1-0 \mathrm{M}$-ammonium sulphate in $10 \mathrm{~mm}$ ammonium acetate buffer (pH 6.8). Fractions in which brominating activity was detected were combined. After addition of ammonium sulphate to $1 \mathrm{M}$ the pooled fractions were rechromatographed on Phenyl-Superose as described above.

Chelating Sepharose $6 \mathrm{~B}$. After the two purification steps with Phenyl-Superose the pooled active fractions were dialysed against $20 \mathrm{~mm}$-sodium phosphate buffer ( $\mathrm{pH} 7 \cdot 0$ ) and applied to a Chelating Sepharose $6 \mathrm{~B}$ column (Pharmacia-LKB) saturated with $\mathrm{Cu}^{2+}$ and equilibrated with $20 \mathrm{~mm}$-sodium phosphate buffer ( $\mathrm{pH} 7 \cdot 0$ ). Proteins were eluted with the same buffer. Fractions with brominating activity were combined.

Further purification of bromoperoxidase 2 (BPO 2)

Heat treatment. The 'pool 2' fractions from DEAE-Sephacel chromatography were incubated at $70^{\circ} \mathrm{C}$ for $10 \mathrm{~min}$ and then centrifuged at $22100 \mathrm{~g}$. After dialysis against $10 \mathrm{~mm}$-ammonium acetate buffer ( $\mathrm{pH} \mathrm{6.8)}$ for $15 \mathrm{~h}$ and concentration by ultrafiltration with a PM-10 membrane, the supernatant solution was used for further purification.

Phenyl-Superose HR 5/5. Ammonium sulphate was added to the concentrated protein solution to $0.4 \mathrm{M}$. The solution was then applied to a Phenyl-Superose HR 5/5 column equilibrated with 0.4 M-ammonium sulphate in $10 \mathrm{~mm}$-ammonium acetate buffer $(\mathrm{pH} \mathrm{6.8)}$. Protein was eluted with a descending gradient of $0.4-0 \mathrm{M}$-ammonium sulphate in $10 \mathrm{mM}$-ammonium acetate buffer (pH 6.8). Fractions showing brominating activity were pooled and dialysed against PBS $(0.13 \mathrm{M}-\mathrm{NaCl}$, $0.007 \mathrm{M}-\mathrm{Na}_{2} \mathrm{HPO}_{4}, 0.003 \mathrm{M}-\mathrm{NaH}_{2} \mathrm{PO}_{4}$ ).

Purification of bromoperoxidase from $S$. aureofaciens Tü24 cloned in $S$. lividans TK64. The enzyme was purified as described by van Pée (1988).

Immunoaffinity chromatography. Antibodies (IgG) against bromoperoxidase from $S$. aureofaciens $T u ̈ 24$ were purified by chromatography on a Protein-A-Sepharose CL-4B column (Pharmacia-LKB) according to the method of Goding (1976). The isolated antibodies were coupled to $p$-nitrophenyl-agarose as described by Wilchek \& Miron (1982). The protein solution from the Phenyl-Superose column was applied to this immunoaffinity column $(2 \mathrm{ml})$ at a flow rate of $8 \mathrm{ml} \mathrm{h}^{-1}$. The crossreactive $\mathrm{BPO} 2$ was eluted with $0.05 \mathrm{M}$-glycine $/ \mathrm{NaOH}$ buffer ( $\mathrm{pH} 10.9$ ) and $25 \%(\mathrm{v} / \mathrm{v})$ ethylene glycol. Samples with brominating activity were pooled.

Preparative PAGE. The concentrated extract after immunoaffinity chromatography was fractionated by native PAGE at pH 7.5. The gel segment containing the enzyme was cut-out and the protein was eluted for $15 \mathrm{~h}$ with $10 \mathrm{mM}$-ammonium acetate buffer ( $\mathrm{pH} \mathrm{6.8)}$.

$M_{r}$ determination. The $M_{\mathrm{r}}$ values of purified BPO 1 and BPO 2 were estimated by molecular-sieve chromatography with a $90 \times 2 \mathrm{~cm}$ column of Sephacryl S 300 HR (Pharmacia-LKB) equilibrated with $50 \mathrm{~mm}$-ammonium acetate buffer (pH 6.8). Ferritin $\left(M_{\mathrm{r}} 440000\right)$, gamma globulin (168000), bovine serum albumin (68000) and cytochrome $c(12000)$ were used as standards.

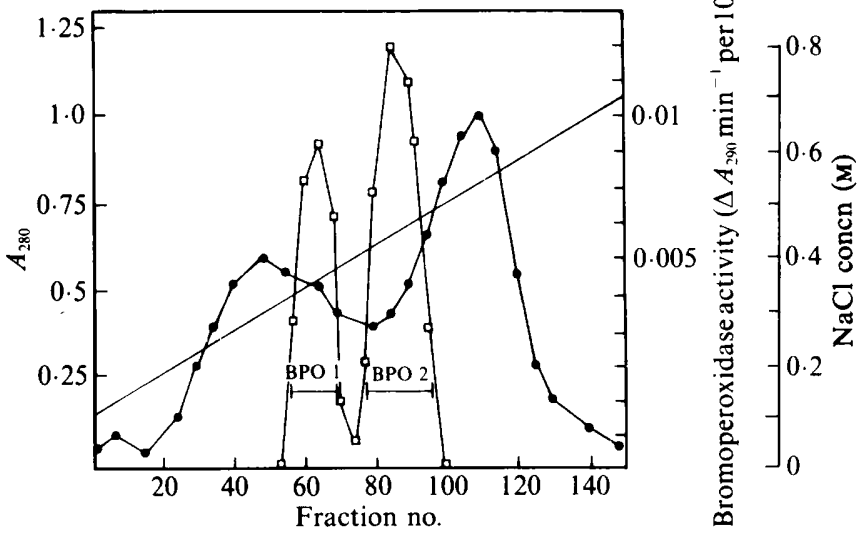

Fig. 1. Chromatography on DEAE-Sephacel showing the separation of the two bromoperoxidase activities, BPO 1 and BPO 2, present in extracts from $S$. aureofaciens ATCC 10762. Fractions of vol. $4 \mathrm{ml}$ were collected. Absorbance at $280 \mathrm{~nm}$; $\square$, bromoperoxidase activity; ,$- \mathrm{NaCl}$ concentration.

\section{Results}

\section{Purification of BPO 1 and BPO 2 from S. aureofaciens ATCC 10762}

No brominating activity could be detected in the crude extract or in fractions obtained by ammonium sulphate precipitation. After the first chromatographic step, brominating activity could be measured. Fractions assayed for brominating activity after chromatography on DEAE-Sephacel exhibited two peaks (Fig. 1). The peak fractions were pooled separately, and the enzymes were purified (Table 1).

After chromatography on Sephacryl S 300 HR, BPO 1 activity could be detected by activity staining with phenol red on native PAGE. The protein-staining band corresponding to this activity was hardly visible; however, a strong protein band which did not show any brominating activity was present (Fig. 2). From $1700 \mathrm{~g}$ wet wt of bacteria about $90 \mu \mathrm{g}$ of BPO 1 were isolated.

Purification of BPO 2 by procedures similar to those used for BPO 1 gave low enrichments of enzyme activity. Therefore, an immunoaffinity purification step was included. Specific interaction between the enzyme and antibodies raised against the bromoperoxidase from $S$. aureofaciens Tü24 led to strong binding of crossreactive protein on the immunoaffinity column. Because desorption of the enzyme required $0.05 \mathrm{M}$-glycine $/ \mathrm{NaOH}$

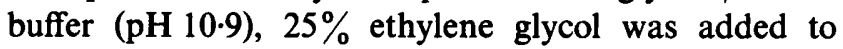
increase enzyme stability. With immunoaffinity chromatography a 500-fold overall purification was obtained, but PAGE detected an additional protein, co-purif- 


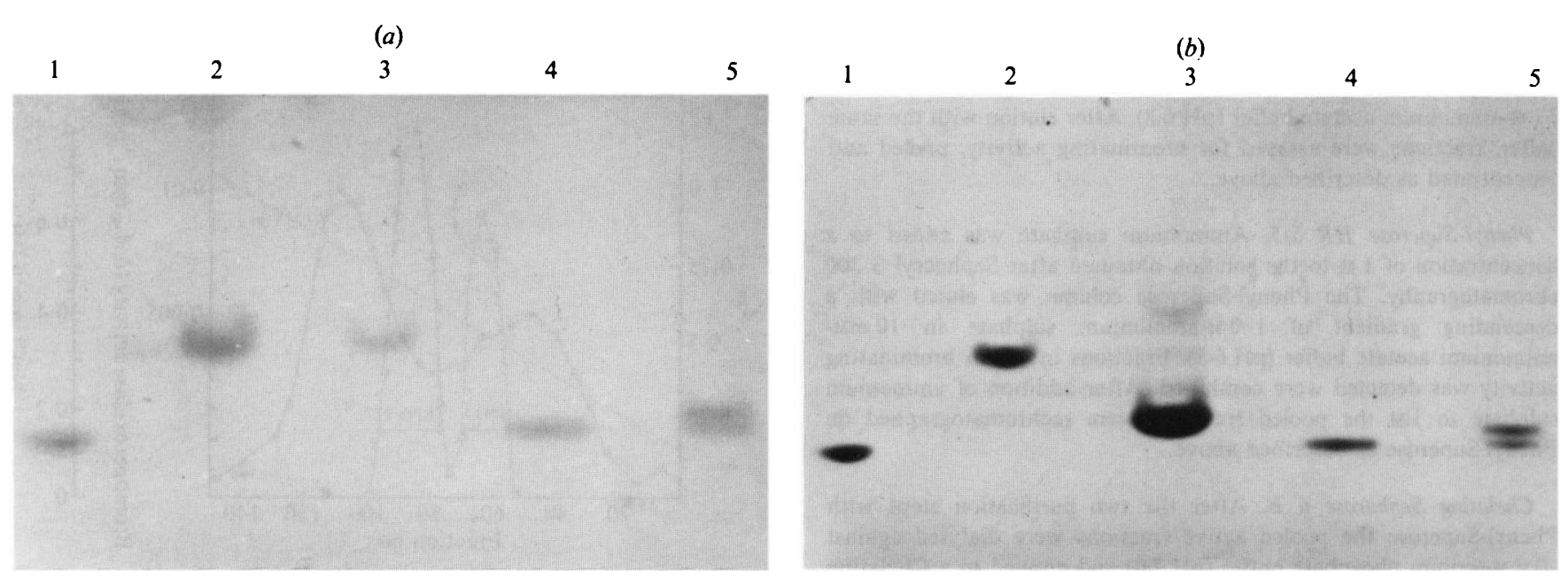

Fig. 2. Native PAGE of bromoperoxidase from S. aureofaciens Tü24, and BPO 1 and BPO 2 from S. aureofaciens ATCC 10762. (a) Activity staining with phenol red for brominating activity; (b) protein staining with Serva Blue R. Lanes: $1,3 \cdot 2 \mu \mathrm{g}$ bromoperoxidase from $S$. aureofaciens Tü24; 2, 3.2 $\mathrm{g}$ BPO $1 ; 3,32 \mu \mathrm{g}$ partially purified BPO 1 after molecular-sieve chromatography; 4, 3.2 $\mu \mathrm{g}$ BPO 2 ; 5 , mixture of $1.6 \mu \mathrm{g}$ bromoperoxidase from $S$. aureofaciens Tü24 and $1.6 \mu \mathrm{g}$ BPO 2 .

Table 1. Purification of BPO I and BPO 2 from S. aureofaciens ATCC 10762

The enzymes were purified from $1700 \mathrm{~g}$ (wet wt) bacteria. -, Could not be determined.

\begin{tabular}{|c|c|c|c|c|c|}
\hline $\begin{array}{l}\text { Purification } \\
\text { step }\end{array}$ & $\begin{array}{l}\text { Total } \\
\text { protein } \\
(\mathrm{mg})\end{array}$ & $\begin{array}{l}\text { Total } \\
\text { activity } \\
\text { (U) }\end{array}$ & $\begin{array}{c}\text { Specific } \\
\text { activity } \\
{\left[\mathrm{U}(\mathrm{mg} \text { protein })^{-1}\right]}\end{array}$ & $\begin{array}{l}\text { Purification } \\
\text { (-fold) }\end{array}$ & $\begin{array}{c}\text { Recovery } \\
(\%)\end{array}$ \\
\hline Crude extract & 37800 & - & - & - & - \\
\hline$\left(\mathrm{NH}_{4}\right)_{2} \mathrm{SO}_{4}$ ppt. & 13912 & - & - & - & - \\
\hline \multicolumn{6}{|l|}{ BPO 1} \\
\hline DEAE-Sephacel & $479 \cdot 7$ & 7.06 & 0.015 & 1 & 100 \\
\hline Heat treatment & 321.8 & $14 \cdot 7$ & 0.046 & 3.06 & $208 \cdot 2$ \\
\hline Sephacryl S 300 & $37 \cdot 38$ & 14.07 & $0 \cdot 367$ & 25.06 & $199 \cdot 3$ \\
\hline 1st Phenyl-Superose & 0.53 & $10 \cdot 05$ & $19 \cdot 0$ & $1266 \cdot 6$ & 142.4 \\
\hline 2nd Phenyl-Superose & $0 \cdot 19$ & 6.68 & $35 \cdot 18$ & $2345 \cdot 3$ & $94 \cdot 6$ \\
\hline Chelating Sepharose & 0.087 & $4 \cdot 0$ & $45 \cdot 23$ & $3015 \cdot 3$ & 56.7 \\
\hline \multicolumn{6}{|l|}{ BPO 2} \\
\hline DEAE-Sephacel & $425 \cdot 5$ & $9 \cdot 7$ & 0.022 & 1 & 100 \\
\hline Heat treatment & 256.6 & $8 \cdot 88$ & 0.034 & 1.55 & $91 \cdot 3$ \\
\hline Phenyl-Superose & 19.54 & 9.9 & 0.885 & 4.02 & 101.7 \\
\hline Immunoaffinity chrom. & 0.22 & $3 \cdot 1$ & $10 \cdot 53$ & $478 \cdot 6$ & 31.9 \\
\hline Preparative PAGE & $0 \cdot 107$ & 1.65 & $15 \cdot 4$ & 700 & 16.95 \\
\hline
\end{tabular}

cation of which with BPO 2 was probably due to hydrophobic interactions with the gel matrix. For final purification of BPO 2, immunoaffinity chromatography was followed by preparative PAGE. From $1700 \mathrm{~g}$ (wet wt) of bacteria about $100 \mu \mathrm{g}$ of BPO 2 was isolated. Each of the purified enzymes gave a single band on SDS-PAGE (Fig. 3).

\section{Enzymic activities of BPO 1 and $B P O 2$}

The two purified enzymes showed brominating activity in the presence of sodium azide (Fig. $2 a$ ); therefore, they belong to the group of non-haem bromoperoxidases. That they showed peroxidase activity only in the presence of bromide was demonstrated by activity staining after PAGE. The specific brominating activity of BPO 1 was $45 \mathrm{U}$ (mg protein) ${ }^{-1}$, that of BPO 2 was $15 \mathrm{U}$ (mg protein) ${ }^{-1}$.

The $\mathrm{pH}$ optimum for the bromoperoxidase activity of BPO 1 in $1 \mathrm{M}$-sodium acetate buffer was $\mathrm{pH} 5.5$; that for BPO 2 was $\mathrm{pH} 4.5$.

The stability of the enzymes at higher temperatures was examined by incubation in $0.03 \mathrm{M}$-Tris $/ \mathrm{H}_{2} \mathrm{SO}_{4}$ buffer $(\mathrm{pH} 8.3)$ at 70 and $80^{\circ} \mathrm{C}$ followed by assay at 


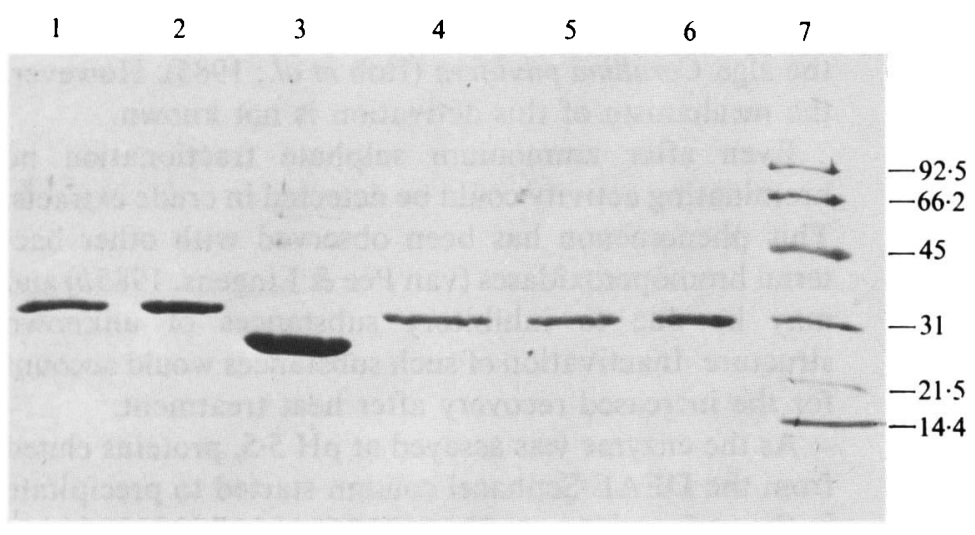

Fig. 3. SDS-PAGE of bromoperoxidase from S. aureofaciens Tü24 and of BPO 1 and BPO 2 from $S$. aureofaciens ATCC 10762. Lanes: $1,6.4 \mu \mathrm{g}$ bromoperoxidase from $S$. aureofaciens $\mathrm{Tü} 24 ; 2,6.4 \mu \mathrm{g}$ BPO 1 ; 3, partially purified BPO 1 after molecularsieve chromatography; 4, 6.4 $\mu \mathrm{g}$ BPO $2 ; 5$, mixture of $3.2 \mu \mathrm{g}$ bromoperoxidase from $S$. aureofaciens Tü24 and $3.2 \mu \mathrm{g}$ BPO $2 ; 6$, mixture of $3.2 \mu \mathrm{g}$ bromoperoxidase from $S$. aureofaciens Tü24 and $3 \cdot 2 \mu \mathrm{g}$ BPO 1; 7, SDS-PAGE marker proteins. The gel was stained with Serva Blue $R$. $25^{\circ} \mathrm{C}$. After $4 \mathrm{~h}$ at $70{ }^{\circ} \mathrm{C}, 64 \%$ of the original brominating activity of BPO 2 was still present. BPO 1 showed no inactivation after $4 \mathrm{~h}$ at $70^{\circ} \mathrm{C}$. Also, after $5 \mathrm{~min}$ at $80^{\circ} \mathrm{C}$, BPO 1 showed no loss of activity, whereas BPO 2 retained only $50 \%$ of its activity.

The $K_{\mathrm{m}}$ values of BPO 1 and BPO 2 for bromide and $\mathrm{H}_{2} \mathrm{O}_{2}$ are listed in the general comparison of properties of all three bromoperoxidases (see Table 3).

\section{Molecular properties of the three bromoperoxidases}

The $M_{\mathrm{r}}$ values estimated from gel chromatography on Sephacryl S 300 HR were 65000 for BPO 1 and 90000 for BPO 2. When a mixture of BPO 2 and bromoperoxidase from $S$. aureofaciens Tü24 was applied to a Superdex 200 column (Pharmacia-LKB) the two enzymes could not be separated. The $M_{\mathrm{r}}$ of the subunits of BPO 1 and BPO 2 determined by SDS-PAGE were identical to those of the bromoperoxidase from $S$. aureofaciens Tü24 (31 000, Fig. 3). Presumably, therefore, BPO 1 consists of two identical subunits and BPO 2 has three identical subunits. During PAGE native BPO 1 migrated more slowly than BPO 2, which was electrophoretically similar to the bromoperoxidase from $S$. aureofaciens Tü24. Mixtures of native BPO 2 and bromoperoxidase from S. aureofaciens Tü24 showed two closely spaced bands on PAGE gels (Fig. 2), but only one band on SDS-PAGE gels (Fig. 3). In isoelectric focusing experiments, BPO 1 gave a single band with a $\mathrm{pI}$ of $4 \cdot 5$, and $\mathrm{BPO} 2$ gave a band of pI $3 \cdot 5$.

\section{Amino acid composition of Tü24 bromoperoxidase and partial sequences of $B P O 1$ and BPO 2 from $A T C C$ 10762}

The result of the amino acid analysis of BPO from S. aureofaciens Tü24 is presented in Table 2 . The enzyme
Table 2. Amino acid composition of bromoperoxidase from S. aureofaciens Tü24

\begin{tabular}{lc}
\hline \multicolumn{1}{c}{$\begin{array}{c}\text { Amino } \\
\text { acid }\end{array}$} & $\begin{array}{c}\text { No. of residues } \\
\text { per subunit }\end{array}$ \\
\hline Aspartic acid & 32 \\
Threonine* $^{*}$ & 20 \\
Serine* & 15 \\
Glutamic acid & 33 \\
Proline & 12 \\
Glycine & 25 \\
Alanine & 31 \\
Valine & 17 \\
Methionine & 1 \\
Isoleucine & 9 \\
Leucine & 23 \\
Tyrosine & 13 \\
Phenylalanine & 16 \\
Lysine & 7 \\
Histidine & 6 \\
Arginine & 12 \\
Tryptophan $\dagger$ & 2 \\
Cysteine & 0 \\
\hline \hline
\end{tabular}

* Values obtained by extrapolating to time zero, assuming first-order decay.

† Tryptophan was determined by the method described by Liu (1972).

$\ddagger$ Cysteine was determined as cysteic acid according to the method described by Hirs (1967).

contained no cysteine and only one methionine; acidic amino acids predominated over basic residues.

The $\mathrm{NH}_{2}$-terminal amino acid sequence of BPO 1 was $\mathrm{NH}_{2}$-Pro-Ile-Ser-Thr-Thr-Arg-Asp-Gly-Val-GluIle-Phe-Tyr-Lys-Asp-Asp-Gly-Gln-Gly-Arg-; that of BPO 2 was $\mathrm{NH}_{2}$-Pro-Phe-Ile-Thr-Val-Gly-Gln-GluAsn-Ser-Thr-Ser-Ile-Asp-Leu-Tyr-Tyr-Glu-Asp-His-, which is identical to the sequence of the first twenty $\mathrm{NH}_{2}$-terminal amino acids of the bromoperoxidase from S. aureofaciens Tü24 (van Pée, 1988). 


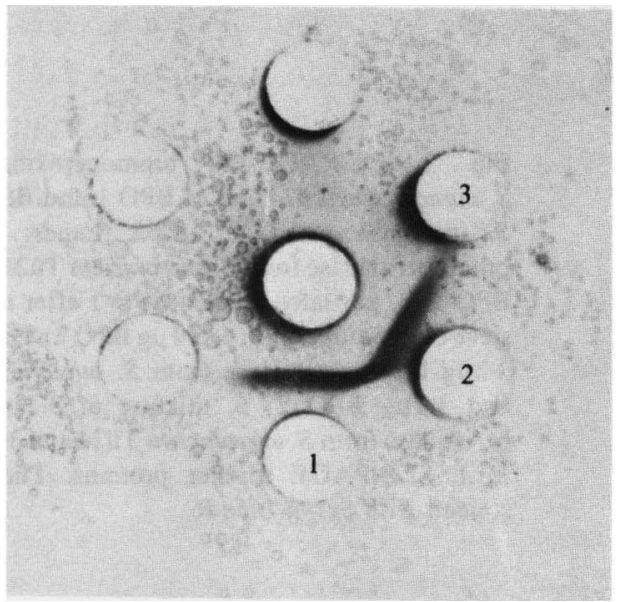

Fig. 4. Ouchterlony gel diffusion assay. The central well contained antiserum raised against bromoperoxidase from $S$. aureofaciens Tü24. Well 1 contained bromoperoxidase from $S$. aureofaciens Tü24, well 2 BPO 2 from $S$. aureofaciens ATCC 10762 and well 3 BPO 1 from S. aureofaciens ATCC 10762.

\section{Immunological investigations of the three bromoperoxidases}

The titre of the serum prepared against bromoperoxidase from $S$. aureofaciens Tü24, as determined by the Ouchterlony assay, was $1: 32$. When the two bromoperoxidases from $S$. aureofaciens ATCC 10762 were examined with the same serum in the Ouchterlony assay, BPO 1 showed no cross-reaction whereas BPO 2 exhibited an identical cross-reaction (Fig. 4). Similar results were obtained in immunoblotting experiments (data not shown).

\section{Partial purification of bromoperoxidase activity from S. aureofaciens Tü24}

Extracts of cells of $S$. aureofaciens Tü24 grown on the medium described for $S$. aureofaciens ATCC 10762 did not contain a bromoperoxidase corresponding to BPO 1 from the latter strain. After partial purification only an enzyme immunologically identical with BPO 2 could be detected spectrophotometrically or by activity-staining native PAGE gels with phenol red.

\section{Discussion}

Since the two bromoperoxidases isolated and purified from $S$. aureofaciens ATCC 10762 were not inhibited by azide, they belong to the class of non-haem haloperoxidases. That they show peroxidase activity in the presence of bromide was demonstrated by activity staining. Stimulation of peroxidase activity by bromide has been reported previously for bromoperoxidase from the alga Corallina pilulifera (Itoh et al., 1985). However, the mechanism of this activation is not known.

Even after ammonium sulphate fractionation no brominating activity could be detected in crude extracts. This phenomenon has been observed with other bacterial bromoperoxidases (van Pée \& Lingens, 1985b) and may be due to inhibitory substances of unknown structure. Inactivation of such substances would account for the increased recovery after heat treatment.

As the enzyme was assayed at $\mathrm{pH} 5 \cdot 5$, proteins eluted from the DEAE-Sephacel column started to precipitate in the assay mixture and made it impossible to measure brominating activity. This could be avoided by dialysing against sodium acetate buffer (pH 5.5) before applying the protein solution to the DEAE-Sephacel column.

BPO 1 and BPO 2 could be separated by ion-exchange chromatography on DEAE-Sephacel; however, when the proteins were eluted too fast, the two brominating activities were not separated. This could explain why Krenn et al. (1988) did not detect two brominating enzymes at this purification step.

Krenn et al. (1988) reported that the bromoperoxidase they isolated from $S$. aureofaciens ATCC 10762 was homogeneous after ammonium sulphate precipitation, ion-exchange chromatography on DEAE-Sephacel and molecular-sieve chromatography. However, at this stage of purification BPO 1, which accounts for the main brominating activity in extracts from $S$. aureofaciens ATCC 10672, is not the major protein. On polyacrylamide gels BPO 1 was visible only when large amounts of protein were loaded. Krenn et al. (1988) obtained $1 \mathrm{mg}$ of homogeneous bromoperoxidase from $100 \mathrm{~g}$ of cells, whereas we could isolate only $87 \mu \mathrm{g}$ of homogeneous BPO 1 from $1700 \mathrm{~g}$ of cells. However, after molecularsieve chromatography we still had $37 \mathrm{mg}$ of protein. From these findings we conclude that the protein Krenn et al. (1988) thought was homogeneous bromoperoxidase was actually a different protein and the two bromoperoxidases were present only in very small quantities which could not be detected by staining for protein. As the activity stain used by Krenn et al. (1988) is not very sensitive, only one bromoperoxidase could be detected. The improved phenol red assay used by us is even more sensitive than staining of proteins with Serva Blue $\mathbf{R}$.

The properties of the three bromoperoxidases are summarized in Table 3. BPO 1, which eluted first during chromatography on DEAE-Sephacel, showed no immunological cross-reaction with serum raised against bromoperoxidase from $S$. aureofaciens Tü24. On the other hand, the bromoperoxidase (BPO 2) that was eluted at a higher salt concentration cross-reacted with the serum. Therefore, BPO 2 from $S$. aureofaciens ATCC 10762 and the bromoperoxidase from $S$. aureofaciens 
Table 3. Comparison of BPO 1 and BPO 2 from S. aureofaciens ATCC 10762, bromoperoxidase isolated from S. aureofaciens ATCC 10762 by Krenn et al. (1988) and bromoperoxidase from S. aureofaciens $T \ddot{2} 24$

ND, Not determined.

\begin{tabular}{|c|c|c|c|c|}
\hline \multirow[b]{2}{*}{ Property } & \multicolumn{2}{|c|}{ S. aureofaciens ATCC 10762} & \multirow{2}{*}{$\begin{array}{l}S . \text { aureofaciens Tü24 } \\
\text { bromoperoxidase }\end{array}$} & \multirow{2}{*}{$\begin{array}{c}\text { S. aureofaciens ATCC } 10762 \\
\text { bromoperoxidase } \\
\text { (Krenn et al., 1988) }\end{array}$} \\
\hline & BPO 1 & BPO 2 & & \\
\hline$M_{\mathrm{r}}$ & 65000 & $90000-95000$ & $90000-95000$ & 65000 \\
\hline Subunit $M_{\mathrm{r}}$ & 31000 & 31000 & 31000 & 32000 \\
\hline No. of subunits & 2 & 3 & 3 & 2 \\
\hline pI & $4 \cdot 5$ & $3 \cdot 5$ & $3 \cdot 5$ & $3 \cdot 5$ \\
\hline $\begin{array}{l}\text { Specific activity } \\
{\left[\mathrm{U}(\mathrm{mg} \text { protein })^{-1}\right]}\end{array}$ & $45 \cdot 2$ & $15 \cdot 4$ & 8.9 & 65 \\
\hline Immunological & - & + & + & ND \\
\hline$K_{\mathrm{m}}\left(\mathrm{Br}^{-}\right), \mathrm{M}$ & $3.9 \times 10^{-2}$ & $1.9 \times 10^{-2}$ & $5.9 \times 10^{-2}$ & $2.0 \times 10^{-2}$ \\
\hline $\begin{array}{l}K_{\mathrm{m}}\left(\mathrm{H}_{2} \mathrm{O}_{2}\right), \mathrm{M} \\
\text { Heat-stability }\end{array}$ & $5.5 \times 10^{-3}$ & $1.6 \times 10^{-3}$ & $3 \cdot 1 \times 10^{-3}$ & $8.0 \times 10^{-3}$ \\
\hline $\begin{array}{l}\text { Heat-stability } \\
\qquad\left(70^{\circ} \mathrm{C}, 4 \mathrm{~h}\right) \\
\left(80^{\circ} \mathrm{C}, 5 \mathrm{~min}\right)\end{array}$ & $\begin{array}{l}100 \% \\
100 \%\end{array}$ & $\begin{array}{l}64 \% \\
50 \%\end{array}$ & $\begin{array}{l}100 \% \\
100 \%\end{array}$ & $\begin{array}{l}20 \% \\
\text { ND }\end{array}$ \\
\hline
\end{tabular}

Tü24 must possess many identical epitopes. The similarity of these two enzymes was confirmed when the sequence of the first twenty amino acids of the $\mathrm{NH}_{2}-$ terminus of BPO 2 proved identical with that of the bromoperoxidase from $S$. aureofaciens Tü24 (van Pée, 1988), whereas the sequence of BPO 1 was dissimilar.

Although BPO 2 and the bromoperoxidase from S. aureofaciens Tü24 exhibited similar immunological properties, isoelectric points, and $\mathrm{NH}_{2}$-terminal amino acid sequences the two enzymes were not identical and could be separated by native PAGE. However, these two bromoperoxidases are so closely related that BPO 2 cannot be the protein of which Krenn et al. (1988) reported the amino acid composition, as the latter was very different from the composition we obtained (see Table 2) for the bromoperoxidase from $S$. aureofaciens Tü24. Therefore, we assume that the bromoperoxidase described by Krenn et al. (1988) corresponds to BPO 1 .

No enzyme corresponding to BPO 1 was found in S. aureofaciens Tü24 (van Pée et al., 1987). As this strain produces 7-chlorotetracycline, it is very likely that BPO 2 and the immunologically identical bromoperoxidase from $S$. aureofaciens Tü24 are the chlorinating enzymes involved in 7-chlorotetracycline biosynthesis. Although these enzymes were isolated as bromoperoxidases and do not chlorinate monochlorodimedone, they may be able to chlorinate a more appropriate substrate, as shown for the chloroperoxidase from Pseudomonas pyrrocinia (Wiesner et al., 1988). Thus the possibility that they are chlorinating enzymes remains.

We are grateful to Mrs Nitsche, Institut für Biochemie, Universität Stuttgart, for help with the amino acid analysis. We wish to thank
Dr Kieß, Institut für Lebensmitteltechnologie, Universität Hohenheim and Dr Hauer, BASF, Ludwigshafen, for determining the partial amino acid sequences, and Mrs Sury for skilled technical assistance. This work was supported by the Deutsche Forschungsgemeinschaft (O.P.), by a Heisenberg grant from the Deutsche Forschungsgemeinschaft (K.-H.v.P.), by the Bundesministerium für Forschung und Technologie (FRG) under the contract 0319416A, and by the Fonds der Chemischen Industrie.

\section{References}

Akhrem, A. A. \& Drozhdenyuk, A. P. (1989). Calcium tartrate gel. Analytical Biochemistry 179, 86-89.

arima, K., Imanaka, H., Kousaka, M., Fukuda, A. \& Tamura, G. (1964). Pyrrolnitrin, a new antibiotic substance, produced by Pseudomonas. Agricultural and Biological Chemistry 28, 575-576.

Chatterjee, S., Vining, L. C. \& Westlake, D. W. S. (1983). Nutritional requirements for chloramphenicol biosynthesis in Streptomyces venezuelae. Canadian Journal of Microbiology 29, 247-253.

De Boer, E., Tromp, M. G. M., Plat, H., Krenn, B. E. \& Wever, R. (1986). Vanadium (V) as an essential element for haloperoxidase activity in marine brown algae: purification and characterization of a vanadium (V)-containing bromoperoxidase from Laminaria saccharina. Biochimica et Biophysica Acta 872, 104-115.

DUGGAR, B. M. (1948). Aureomycin, a product of the continuing search for new antibiotics. Annals of the New York Academy of Sciences 51, $177-181$.

Ehrlich, J., BarTz, Q. R., SMITH, R. M., Joslyn, D. A. \& BURKHOLDER, P. R. (1947). Chloromycetin, a new antibiotic from a soil actinomycete. Science 106, 417.

GoDING, J. W. (1976). Conjugation of antibodies with fluorochromes: modification to the standard methods. Journal of Immunological Methods 13, 215-226.

Hewson, W. D. \& Hager, L. P. (1980). Bromoperoxidase and halogenated lipids in marine algae. Journal of Phycology 16, 340-345.

HIRs, C. H. W. (1967). Performic acid oxidation. Methods in Enzymology 11, 197-199.

ItoH, N., IzUMI, Y. \& YAMada, H. (1985). Purification of bromoperoxidase from Corallina pilulifera. Biochemical and Biophysical Research Communications 131, 428-435. 
KrenN, B. E., Plat, H. \& Wever, R. (1988). Purification and some characteristics of a non-haem bromoperoxidase from Streptomyces aureofaciens. Biochimica et Biophysica Acta 952, 255-260.

LiU, T.-Y. (1972). Determination of tryptophan. Methods in Enzymology 25, 44-55.

LOo, T. L., BURGER, J. W. \& ADAMSON, R. H. (1964). Bromination of phthalein dyes by the uterus of the dogfish, Squalus acanthias. Proceedings of the Society of Experimental Biology and Medicine 114, 60-63.

MAURER, H. R. (1964). Disk-Elektrophorese: Theorie und Praxis der diskontinuierlichen Polyacrylamidgelelektrophorese. Berlin: Walter de Gruyter.

Neidleman, S. L. \& Geigert, J. (1986). Biohalogenation: Principles, Basic Roles and Applications. Chichester: Ellis Horwood/John Wiley.

Olsen, R. L. \& Little, C. (1984). Purification and some properties of myeloperoxidase and eosinophil peroxidase from human blood. Biochemical Journal 209, 781-787.

OUCHTERLONY, Ö. (1948). In vitro method for testing the toxinproducing capacity of diphtheria bacteria. Acta Pathologica et Microbiologica Scandinavia 25, 186-191.

VAN PÉE, K.-H. (1988). Molecular cloning and high-level expression of a bromoperoxidase gene from Streptomyces aureofaciens Tü24. Journal of Bacteriology 170, 5890-5894.

van Pée, K.-H. \& Lingens, F. (1985a). Purification of bromoperoxidase from Pseudomonas aureofaciens. Journal of Bacteriology 161, 1171-1175.

van PéE, K.-H. \& Lingens, F. (1985b). Purification and molecular and catalytic properties of bromoperoxidase from Streptomyces phaeochromogenes. Journal of General Microbiology 131, 1911-1916. van Pée, K.-H., Sury, G. \& Lingens, F. (1987). Purification and properties of a nonheme bromoperoxidase from Streptomyces aureofaciens. Biological Chemistry Hoppe-Seyler 368, 1225-1232.

SCHÄGGAR, H. \& vON JAGOW, G. (1987). Tricine-sodium dodecyl sulfate-polyacrylamide gel electrophoresis for the separation of proteins in the range from 1 to $100 \mathrm{kDa}$. Analytical Biochemistry 166, 368-379.

Shannon, L. M., Kay, E. \& Lew, Y. (1966). Peroxidase isoenzymes from horseradish roots. Journal of Biological Chemistry 214, 2166-2172.

SpaCKMan, D. H. (1967). Accelerated methods. Methods in Enzymology 11, 3-27.

VILTER, H. (1983). Peroxidase from Phaeophyceae. III. Catalysis of halogenation by peroxidases from Ascophyllum nodosum. Botanica Marina 26, 429-435.

VILTER, H. (1984). Peroxidase from Phaeophyceae: a vanadium (V)-dependent peroxidase from Ascophyllum nodosum. Phytochemistry 23, 1387-1390.

Wiesner, W., VAN PÉE, K.-H. \& Lingens, F. (1986). Detection of a new chloroperoxidase in Pseudomonas pyrrocinia. FEBS Letters 209, 321-324.

Wiesner, W., van Pée, K.-H. \& Lingens, F. (1988). Purification and characterization of a novel bacterial non-heme chloroperoxidase from Pseudomonas pyrrocinia. Journal of Biological Chemistry 263, $13725-13732$.

WILChEK, M. \& MIRON, T. (1982). Immobilization of enzymes and affinity ligands onto agarose via stable and uncharged carbamate linkages. Biochemistry International 4, 629-635. 